\title{
DOYNE LECTURE RHODOPSIN AND AUTOSOMAL DOMINANT RETINITIS PIGMENTOSA
}

\author{
THADDEUS P. DRYJA \\ Boston, Massachusetts
}

I owe a debt of gratitude to the Master of the Oxford Congress of Ophthalmology for the invitation to be here today. The Congress has been immensely exciting to me and has provided me the opportunity to meet a number of distinguished British ophthalmologists whose work I have studied since specialising in ophthalmology 14 years ago. I want to mention Alan Bird in particular, because his contributions to our understanding of many hereditary retinal diseases have been especially noteworthy. His expertise encompasses most of the topic on which I will be speaking today: retinitis pigmentosa. Here I would like to review the approach my laboratory took to discover a gene responsible for this devastating disease. This work has held my attention for the last seven years.

Retinitis pigmentosa is the name given to a set of retinal degenerations that have a number of clinical characteristics in common (see Table I). Most cases, perhaps all, are hereditary. The genetics of this disease is not simple. The disease is inherited as an autosomal dominant trait in some families, autosomal recessive in others, and as an X-linked trait in still others. Furthermore, linkage studies have demonstrated that families with $\mathrm{X}$-linked retinitis pigmentosa can be further subdivided, since there are at least two distinct loci on the $\mathrm{X}$ chromosome at which mutations can cause the disease. ${ }^{1}$ It is likely that gene locus heterogeneity is also a feature of the autosomal dominant and autosomal recessive forms of retinitis pigmentosa. In some families with recessive disease, congenital or acquired deafness can be a feature, in which case the diagnosis is more appropriately Usher's syndrome type I or type II, respectively. ${ }^{2}$ There is recent evidence pointing to a gene on chromsome 1q as the cause of Usher's syndrome type II. ${ }^{3}$ The gene or genes responsible for Usher's syndrome type I, as well as the genes responsible for other forms of recessive retinitis pigmentosa are somewhere else in the human genome. In fact, there may be dozens of genetic loci where mutations can cause retinitis pigmentosa.

Correspondence to: Thaddeus P. Dryja, MD, Massachusetts Eye and Ear Infirmary, 243 Charles Street, Boston, MA 02114, USA.
One approach to learning about the pathology and biological mechanisms accountable for this disease is to study the retina from the affected patients. Understandably, most specimens donated for such research come from deceased elderly individuals. The retinas of such patients are typically severely degenerated and only an occasional specimen will provide clues as to the pathogenesis of the retinal degeneration. ${ }^{4-8}$ These reports, as well as those describing retinas of the occasional younger patient whose eyes are donated for research postmortem, ${ }^{9,10}$ reveal that the earliest affected cells are the photoreceptors and/or the retinal pigment epithelial cells. A few biochemical analyses have been performed on these rare early cases, but thus far the data do not allow a generally accepted consensus as to the mechanisms accounting for the photoreceptor degeneration.

In view of the numerous patients with the disease

Table I.

I. CLINICAL FEATURES OF RETINITIS PIGMENTOSA

A. Symptoms

1. Night blindness

2. Early loss of peripheral visual field

3. Late loss of central field as well

B. Signs

1. Pallid optic nerve head

2. Attenuated retinal vessels

3. Bone spicule pigmentary deposits in the periphery

4. Posterior subcapsular cataract

C. Electroretinographic abnormalities

1. Reduced amplitude of scotopic and photopic b-wave

2. Delay in time between flash of light and peak of $b$-wave (delayed implicit time)

II. DISTRIBUTION OF CASES ACCORDING TO GENETIC TYPE (based on ref. 12)

A. Autosomal dominant $-43 \%$

B. Autosomal recessive-20\%

C. X-linked-8\%

D. 'Isolate' (i.e. only one affected family member, possibly representing autosomal recessive disease, but could also be new dominant or X chromosome mutation)-23\%

E. Undetermined (i.e. adopted, uncertain family history, etc.)- $-6 \%$ 
$(50,000 \text { to } 100,000 \text { in the United States alone })^{11,12}$ as well as its hereditary nature, it would be reasonable to try molecular genetics approaches to discover the relevant genes and consequently the biochemical defects. Genetic analysis of affected patients does not require retinal tissue, since essentially the same genes are present in all somatic cells. Satisfyingly, the procurement of blood samples for the purification of leucoctye DNA is simple. The question becomes how to identify a gene that causes retinitis pigmentosa among the 50,000 to 100,000 genes that are present in the human genome.

A molecular geneticist can take either of two major routes to achieve this end (see Table II). The first approarh, called the 'linkage' or the 'reverse genetics' approach, depends upon finding a genetic marker in the humian genome that is close to the gene of interest. For this approach to be practical, it is necessary to have available for study one or more large kindreds with scores of affected and unaffected members. After collecting blood samples and purifying DNA from each available family member, the investigator analyses one chromosomal marker after another until he or she finds a marker whose inheritance correlates with the inheritance of the disease trait. Such a positive result indicates that the marker locus and the disease locus are in close proximity on the same chromosome. Since it is easy to ascertain the chromosomal location of a marker, the scientist will soon deduce the approximate location of the gene of interest. Fragments of DNA from that chromosomal region are cloned, and ultimately the investigator aims at finding a DNA sequence that is expressed (i.e., is part of a gene) and is mutant in affected individuals. The final task is to discover what the identified gene does and why defects in it are pathogenic.

The reverse genetics approach is generally expensive, labour-intensive, and time-consuming. It has the advantage that it is almost sure to succeed given enough effort and provided that a sufficiently large family is available for study. It also will work if the same gene is known to cause disease in sets of small families under study.

Table II. Approaches to the identification of a disease gene without prior knowledge of underlying biochemical defect

I. LINKAGE

A. Collect leucocyte DNA from members of large families with the disease.

B. Find a chromosomal marker that is co-inherited with the disease. If such is found, then one knows that the disease gene is 'close' to the marker locus.

C. Clone DNA fragments from the identified chromosomal region.

D. Find sequences conserved during evolution, e.g., that are similar in primates and rodents.

E. Determine whether the conserved sequences are expressed in relevant tissues. If so, clone the corresponding mRNA (cDNA) sequence.

F. Search for mutations in the identified transcriptional unit in patients with the disease.

II. CANDIDATE GENE

A. Collect leucocyte DNA from unrelated patients with genetic disease.

B. Collect cloned genes specific for diseased tissue.

C. Search for mutations in those genes in the patients.
Examples of successes with the technique are the identification of genes causing chronic granulomatous disease, ${ }^{13}$ Duchenne's muscular dystrophy, ${ }^{14}$ cystic fibrosis, ${ }^{15-17}$, and retinoblastoma. ${ }^{18}$ The amount of effort required can sometimes be substantial: the approach still has not provided a gene for Huntington's chorea despite over a decade of work by many research groups, and despite the fact that the chromosomal location of the responsible gene was discovered about eight years ago. ${ }^{19}$

An alternative approach, called the 'candidate gene approach', has the advantage of being more straightforward but the disadvantage of being less assured of success. The investigator selects genes specifically expressed in the diseased tissue or that are known to code for proteins with important functions in that tissue. Patients with the disease are then screened for mutations in each of those genes. There are benefits and drawbacks of this conceptually simple approach. One advantage is that the method works even if there is genetic heterogeneity, since it is necessary that only some patients in the group under inspection have a defect in the selected candidate gene. Another advantage pertains to the fact that the candidate genes are selected because of the known function of their protein products. Consequently, the discovery of a defect in such a gene immediately provides insights into the pathophysiology of the disease. A disadvantage of this method is that it is possible that no patients under study have disease due to the candidate gene or genes that one chooses to examine. This might be the situation if mutations of the tested candidate gene are rare and no patients with them are included in the laboratory's collection. Alternatively, a negative result might only be due to imperfections in the techniques for finding the mutations, i.e. one might overlook the responsible defects. Finally, the reasoning that is used to select a candidate gene might be faulty; e.g. perhaps the gene is essential to life and that mutations are lethal.

My laboratory has pursued the second approach in part because I was fortunate to have the close collaboration of Professor Eliot Berson, who has a large practice devoted to the diagnosis and care of patients with retinitis pigmentosa. Since 1984 we have collected blood samples and purified DNA from hundreds of patients with either retinitis pigmentosa or other forms of hereditary retinal degeneration. Among the over 3,000 patients who have volunteered for our research, we have concentrated our efforts on a subset of 600 patients with retinitis pigmentosa who have been followed annually by Dr. Berson for six years or more. These patients have been subdivided according to the inheritance pattern of the disease: autosomal dominant, autosomal recessive, X-linked, 'isolate', or undetermined'. The 'isolate' cases are those with only one affected family member; most of these patients probably have an autosomal recessive form of disease, but some could be X-linked and others could represent new dominant mutations. The 'undetermined' category includes patients with uncertain family history (e.g. orphans or patients who had been adopted). Blood samples from the relatives of some selected patients have 
also been obtained, although no families large enough for pan-genomic linkage study were ascertained.

This large set of patients fulfills one of the requirements for the candidate gene approach. The second requirement, of course, is the availability of candidate genes ready for analysis. Fortunately, this was no major hurdle. During the 1980 s genes for a number of important photoreceptor proteins had been cloned, including rhodopsin ${ }^{20}$ interphotoreceptor retinoid binding protein, ${ }^{21,22}$ cellular retinaldehyde binding protein ${ }^{23} 48 \mathrm{~K}$ protein (also called arrestin or S-antigen), ${ }^{24}$ the alpha subunits of rod and cone transducin, ${ }^{25}$ the gamma subunit of cGMP-phosphodiesterase, ${ }^{26,27}$ etc. Most of these genes were known to be expressed only in retina, and their protein products were considered to be essential to the functioning of photoreceptors. The only issue in my mind was how often (not whether) these genes were mutant in patients with hereditary photoreceptor dysfunction.

Since those patients with a defect in one of these candidate genes might represent only a small minority of the cases with a given type of retinitis pigmentosa (or even some other hereditary retinal disease), the key was to devise methods that could distinguish those individuals among the hundreds of patients who were available for study. When the actual searching for mutations in these genes was initiated around 1987, the only method available for quickly screening for mutations was the Southern blot technique. This method is excellent for detecting deletions, insertions, and other gene rearrangements, but it has the drawback that it misses most point mutations.

Over the next few years, members of my laboratory used the Southern blot technique to search for mutations in some candidate genes in our 'core' set of 600 patients with retinitis pigmentosa. Despite years of work, we found no mutations with this relatively insensitive technique in the genes coding for rhodopsin, interphotoreceptor retinoid binding protein ${ }^{28}$ cellular retinaldehyde binding protein, ${ }^{29}$ $48 \mathrm{~K}$ protein ${ }^{28}$ the alpha subunits of the rod and cone ${ }^{28}$ transducins, or the gamma subunit of phosphodiesterase. ${ }^{30}$ Realising that we could be missing point mutations, which were at that time detectable only after a tedious, timeconsuming process, we simultaneously took advantage of quicker, indirect methods that could possibly suggest the existence of mutations in our candidate genes. These indirect methods utilise RFLPs, which are naturally occurring variations in the DNA sequence of genes. We located RFLPs in the genes coding for cellular retinaldehyde binding protein, ${ }^{29} 48 \mathrm{~K}$ protein, ${ }^{28}$ the alpha subunit of cone transducin, ${ }^{28}$ and the gamma subunit of phosphodiesterase, ${ }^{30}$ among others. RFLPs in some candidate genes, such as the gene for interphotoreceptor retinoid binding protein, had been discovered by other groups. ${ }^{31,32}$ These RFLPs were used two ways in our studies.

First, although RFLPs in themselves do not ordinarily confer any particular phenotype, they allow one to trace the inheritance of candidate genes through a family to see if any are coinherited along with retinitis pigmentosa. If a specific copy of a gene, identified by its RFLP alleles, was invariably present in all affected members and no unaffected members of a particular family, one would strongly suspect that the gene had a mutation that was causing the disease. However, we never found statistically significant coinheritance of a candidate gene with retinitis pigmentosa in the few pedigrees that were analysed.

The second analysis we performed with RFLPs was based on the concept of linkage disequilibrium. Alleles of RFLPs are typically found to be distributed among individuals according to the Hardy-Weinberg equilibrium (see Table III). Departures from Hardy-Weinberg equilibrium can indicate a bias in the selection of individuals in the set under study. One explanation for such a bias is that a proportion of the individuals in the set descend from a common ancestor, in which case there would be an overrepresentation of an RFLP allele that was carried by that ancestor. If such a result were found among a large set of supposedly unrelated patients with, say, autosomal recessive retinitis pigmentosa, one would have suggestive evidence that the overrepresented allele carries a mutation that was carried by this presumed distant ancestor. At that point one could focus time-consuming techniques of obtaining the DNA sequence of the gene to those individuals with the overrepresented allele. With this reasoning in mind, we used cloned candidate genes with known RFLPs to look for departures from Hardy-Weinberg equilibrium among our sets of patients with various forms of retinitis pigmentosa; we found none.

In spite of these persistently negative results, we were confident that the approach was a sound one and we persevered with it. A milestone in this work occurred in 1989, but not in our laboratory. Dr. Peter Humphries in Dublin, Ireland, had been using the linkage approach in his studies of a large Irish pedigree with autosomal dominant retinitis pigmentosa. This was the first approach discussed above; the one we had not taken. Dr. Humphries announced in August that he had discovered a marker that was closely

Table III. Hypothetical example of linkage disequilibrium

\begin{tabular}{clccc}
\hline $\begin{array}{l}\text { RFLP alleles } \\
\text { at the } \\
\text { hypothetical } \\
\text { test locus }\end{array}$ & $\begin{array}{l}\text { Number of } \\
\text { control } \\
\text { subjects with } \\
\text { given RFLP } \\
\text { alleles } \\
\text { among } \\
\text { group of } 100\end{array}$ & $\begin{array}{l}\text { 100 patients with recessive retinitis } \\
\text { pigmentosa, 20 of whom descend from } \\
\text { a shared ancestor with the '1' allele at } \\
\text { the test locus }\end{array}$ \\
$\begin{array}{ccccc}80 \text { not from } \\
\text { ancestor }\end{array}$ & $\begin{array}{c}\text { 20 from } \\
\text { ancestor }\end{array}$ & Sum \\
\hline 1,1 & 25 & 20 & 20 & 40 \\
1,2 & 50 & 40 & 0 & 40 \\
2,2 & 25 & 20 & 0 & 20 \\
\hline Totals & 100 & & & 100 \\
\hline
\end{tabular}

According to Hardy-Weinberg equilibrium if two codominant alleles are in a 50:50 proportion in a population, then the genotypes among a group of 100 individuals from that population should approximate the numbers given above. In contrast, the 100 patients with autosomal recessive retinitis pigmentosa do not have this distribution because 20 of them descend from a single ancestor who had the ' 1 ' allele at the test locus and who had a mutation causing the disease in that allele. These 20 patients are all homozygous for the mutation causing retinitis pigmentosa and consequently are ' 1,1 ' homozygotes for the RFLP. A statistical test such as Chi-square will provide the likelihood that the differences in the two groups are statistically significant. 
linked to the disease gene in this family. Since the marker was derived from the long arm of chromosome 3, the disease gene must be on that same chromosome arm. When we heard this news a specific candidate gene came to mind because it was known to be on the same chromosome arm: the rhodopsin gene. ${ }^{33,34}$ Until that time, we had done little work with the rhodopsin gene because no informative RFLPs were known to be at the locus. We had done some Southern blot studies to look for gene deletions or rearrangements and had found none among over 100 patients whom we analysed (unpublished results). After learning about Humphries' results, however, we suspended work on other candidate genes and devoted the major portion of the laboratory's resources to searching for point mutations in the rhodopsin gene in our patients with autosomal dominant retinitis pigmentosa.

Since we already knew that deletions of the gene were not present in our patients, we decided to use advanced methods based on the technique called the polymerase chain reaction (PCR) for rapidly sequencing DNA from a specified gene. We had previously gained some experience with this technique from our efforts at finding point mutations in the retinoblastoma gene in patients with retinoblastoma. ${ }^{35,36}$ The application of the method to the rhodopsin gene was facilitated by the fact that Dr. Jeremy Nathans had already determined the gene's complete DNA sequence..$^{20} \mathrm{~A}$ map of the gene, based on Nathans' results, is shown in Figure 1. We developed a protocol for directly sequencing the coding sequence from the rhodopsin gene and selected 20 unrelated patients with autosomal dominant retinitis pigmentosa for this intensive analysis. Within six weeks of learning of Humphries' findigns, a research assistant in my laboratory, Terri McGee, had discovered the same point mutation in five of those patients. ${ }^{37}$ This mutation changed a cytosine to an adenine (a 'C-to-A transversion') in codon 23. This codon normally specifies proline as the $23 \mathrm{rd}$ amino acid in the sequence of human rhodopsin; with the C-to-A mutation the codon would instead specify histidine.

We sought additional evidence that this alteration in the DNA sequence was a cause of retinitis pigmentosa. Further testing revealed that about $10 \%$ of our patients with autosomal dominant retinitis pigmentosa carried this mutation; none of over 100 unrelated, unaffected individuals did. In a few families, we were able to trace the inheritance of this mutation through three generations; it perfectly correlated with the inheritance of retinitis pigmentosa. Finally, it was likely that the proline at position 23 was important to the structure or function of rhodopsin since that amino acid has not changed during evolution among the vertebrate rod and cone opsins. ${ }^{38-40}$

This discovery of a cause for retinitis pigmentosa prompted our group and other groups to search for other mutations in the rhodopsin gene. In all, over 30 distinct mutations have been discovered among patients with dominant retinities pigmentosa in North America, Europe, and Japan (see Table IV). In every family so far studied, the mutation invariably was coinherited with the disease.
No unaffected individual has been found to carry any of these mutations. Combining all of this data, it appears that mutations in the rhodopsin gene are the cause of about $25-30 \%$ of cases of dominant retinitis pigmentosa. The remaining cases are due to defects at other loci, and the search for those loci is understandably under active investigation.

Faced with a sudden abundance of new data about a disease, one strives to make sense of it and to organise it in a rational manner. There are a variety of approaches one can take to analyse this data. Now I will consider what this set of mutations tells us about the mutability of the rhodopsin gene. I will speculate on the possible pathogenic properties of the mutant rhodopsin molecules that are encoded by these abnormal alleles. Finally, I will review some of the clinical characteristics of the patients who carry these mutations.

Mutations are of fundamental importance to genetics, and the subject would be quite boring without them. Hence, geneticists have developed categorisation schemes for them. Mutations can affect a single base pair (point mutations), or many base pairs. They can be deletions ranging in size between one base pair and millions of base pairs. They can be insertions of DNA from another locus, insertions or duplications of DNA from the same locus, or inversions, translocation, etc. The mutations so far found in the DNA sequence of the rhodopsin gene are almost all of one category: point mutations. As shown in Table IV, they are more frequently transitions (substitution of a purine base for another purine, or a pyrimidine base for another pyrimidine) rather than transversions (substitution of a purine for a pyrimidine or vice versa. Among the transitions, the changes C-to-T and G-to-A (which are really the same mutation, the difference depending on whether one reads the sense or antisense strand of DNA) are the most frequent. Is this preference for these two related transitions (among the twelve possible single base substitutions) specific to the rhodopsin gene, possibly telling us something about retinitis pigmentosa or the mutability of this gene? Probably not, since this bias for transitions, and especially the C-to-T and G-to-A transitions, is a feature of the point mutations found at many loci. It may relate to the as yet poorly defined mechanisms responsible for germline mutations in humans.

Another interesting feature of these mutations is their rarity. Most of them are found in only one family, indicating that many of them might have arisen in a single ancestor of each family. The first mutation we discovered, the Pro23His mutation, is an extreme example of this. The 17 'unrelated' families that we have described with this mutation all carry the same rare marker at a microsatellite polymorphism within the first intron of the rhodopsin gene, ${ }^{41}$ in addition to the C-to-A transversion in codon $23 .{ }^{42}$ It is more likely that the pro23His mutation arose only once on a copy of the rhodopsin gene with this uncommon microsatellite allele than many times but always on a rhodopsin allele that happened to have this rare microsatellite sequence. In support of the idea that 


\section{MAP OF THE HUMAN RHODOPSIN GENE WITH LOCATIONS OF DNA POLYMORPHISMS AND SOME MUTATIONS}

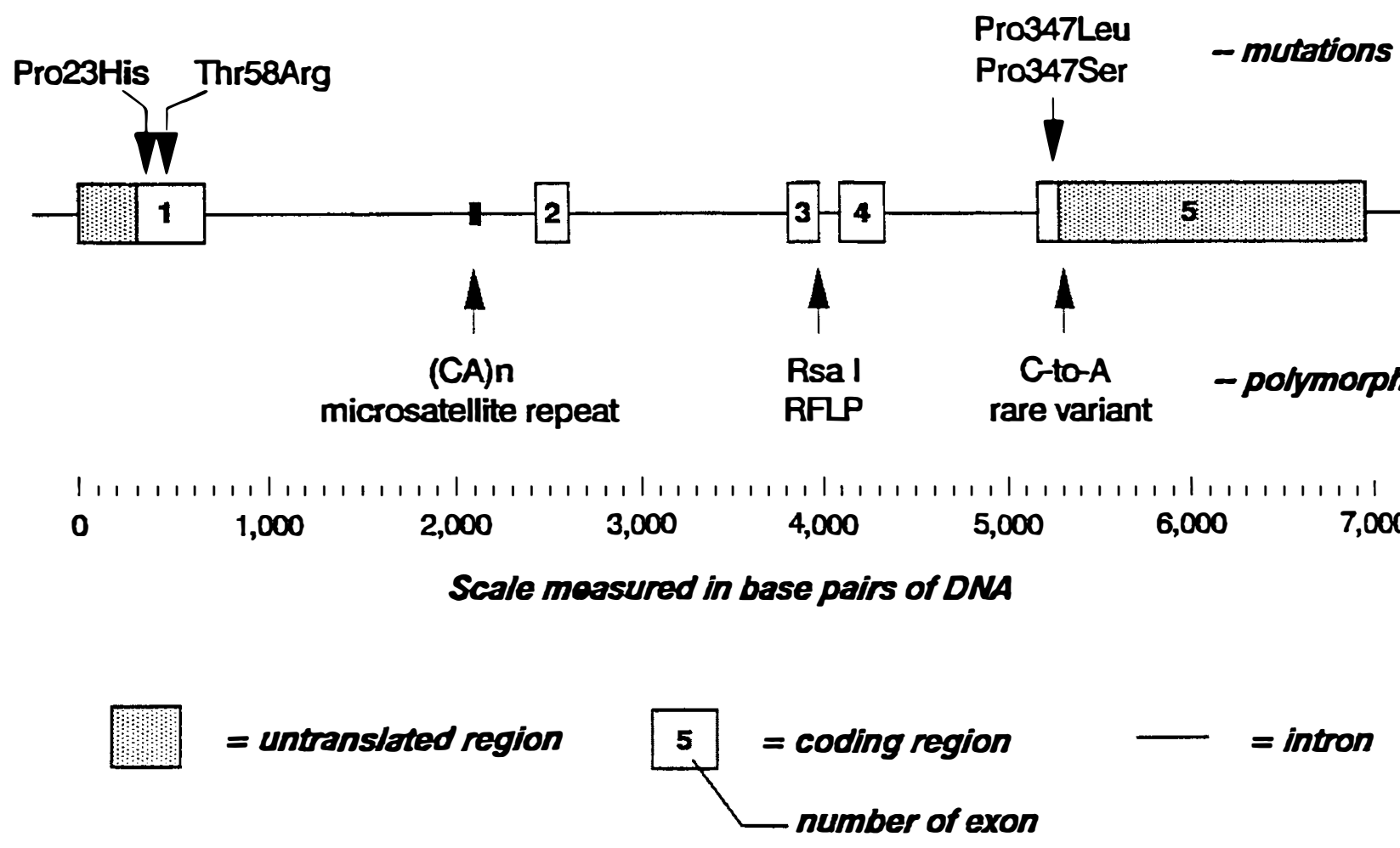

Fig. 1. Map of the human rhodopsin gene. To the left is the 5' end of the gene; to the right is the 3' end. The orientation of this gene with regard to the centromere and telomere of chromosome 3 is not yet known. The map shows the positions of polymorphisms in the gene that are found in humans. Also shown are the approximate positions of some of the early mutations found among patients with dominant retinitis pigmentosa.

these 'unrelated' familes share a common ancestor is the fact that the Pro23His mutation has never been found in Europe or Asia. Coupling that information with the ancestry from pre-revolutionary settlers to North America that some of these 17 families claim, it becomes clear that the founder of this mutuation might have been an early colonist, possibly from Great Britain.

A few of the mutations, however, definitely occurred more than once in human history. A C-to-T transition in codon 347, changing the codon from specifying proline to specifying leucine (Pro347Leu), is an example of this. We have found the Pro347Leu mutation in eight unrelated families. ${ }^{42}$ Analysis of the microsatellite repeat polymorphism in intron 1 indicates that there are at least two separate founders of this mutation among seven of these families. Furthermore, the eighth family presented us with the only instance we could find of a new germline mutation in the rhodopsin gene. In this family the Pro347Leu mutation was present in a patient and her child but not in her parents. This mutation has been found also in Great Britain $^{43}$ and in Japan, ${ }^{44}$ presumably having arisen in yet other founders. The explanation for this relative 'hotspot' for mutations in the rhodopsin gene might be that codon 347 is unusually susceptible to the obscure mechanisms responsible for C-to-T transitions in the human germline.
Most of the mutations are missense mutations, i.e. they would be expected to cause a substitution of one amino acid for another in rhodopsin. A few of them are deletions or point mutations that would result in the removal of one or a few amino acids in the protein. None of the mutations appear to be null mutations, i.e. mutations that would result in little or no protein product. In view of this, it appears that the disease associated with these mutations is due to the production of a mutant form of rhodopsin that is somehow toxic to photoreceptors.

Consequently, a tabulation of which regions of the protein are affected by these amino acid substitutions might reveal insights as to the nature of this supposed toxicity. Figure 2 shows a schematic representation of the rhodopsin molecule. According to current models, this protein traverses the disc membrane seven times. The amino terminal end is in the intradiscal space, and the carboxy terminus is in the cytoplasm. The circles indicate amino acids affected by the mutations seen in patients with autosomal dominant retinitis pigmentosa. Note that they could be divided into three groups according to the location of the affected amino acids in rhodopsin (see Table IV). In the first group are mutations that affect amino acids in the intradiscal space. Many of these affecting amino acids near the cysteines involved in a disulfide bond connecting 
Table IV. Mutations found in tite rhodopsin gene in patients with autosomal dominant retinitis pigmentosa

\begin{tabular}{ll}
\hline No. Mutation References & $\begin{array}{l}\text { Transition/ } \\
\text { transversion }\end{array}$ \\
\hline
\end{tabular}

Group I-mutations affecting amino acids in the intradiscal space

$\begin{array}{rlll}\text { 1. } & \text { Thr17Met } & 50-53,57 & \text { transition } \\ \text { 2. } & \text { Pro23His } & 37,42,50-54,60,62,63 & \text { transversion } \\ \text { 3. } & \text { Pro23Leu } & 51 & \text { transition } \\ \text { 4. } & \text { Gly106Trp } & 52,53 & \text { transversion } \\ \text { 5. } & \text { Cys110Tyr } & \text { [author's laboratory, unpublished } & \text { transition } \\ \text { 6. } & \text { Tyr178Cys } & 52,64 & \text { transition } \\ \text { 7. } & \text { Glu181Lys } & 51 & \text { transition } \\ \text { 8. } & \text { Gly182Ser } & 50 & \text { transition } \\ \text { 9. } & \text { Ser186Pro } & 51 & \text { transition } \\ \text { 10. } & \text { Gly188Arg } & 51 & \text { transition } \\ \text { 11. } & \text { Asp190Asn } & 51,65 & \text { transition } \\ \text { 12. } & \text { Asp190Gly } & 51-53 & \text { transition }\end{array}$

Group II-mutations affecting amino acids in transmembrane domains

\begin{tabular}{llll} 
13. & Phe45Leu & 52,53 & \multicolumn{1}{c}{$\begin{array}{l}\text { transition } \\
\text { 14. }\end{array}$} \\
15. & Gly51Arg & [author's laboratory, unpublished & $\begin{array}{l}\text { transition } \\
\text { 15. }\end{array}$ \\
16. & Thr58Arg & $42,50-53,57,58,61$ & transversion \\
17. & Val87Asp & 52,53 & transversion \\
18. & Gly89Asp & $51-53$ & transition \\
19. & Leul25Arg & 51 & 2 transversions \\
20. & Arg135Leu & $52,53,57$ & transition \\
21. & Arg135Trp & $52,53,57$ & transition \\
22. & Cys167Arg & 51 & transition \\
23. & Pro171Leu & 51 & transversion \\
24. & His211Pro & 65 & neither \\
25. & Ile255Del & 43,66 & transition \\
26. & Pro267Leu & 50 & transition \\
27. & Lys296Glu & 65 & \\
Group III-mutations affecting amino acids in the cytoplasm \\
28. & Del68-71 & 65 & neither \\
29. & Gln344Ter & $52,53,57$ & transition \\
30. & Val345Met & 51,59 & transition \\
31. & Pro347Arg & 67 & transversion \\
32. & pro347Leu & $42-44,51-53,56$ & transition \\
33. & Pro347Ser & 42,51 & transition \\
\hline
\end{tabular}

the first and second intradiscal loops. In the second group are mutations affecting amino acids in the transmembrane regions. Many of these mutations replace a hydrophobic amino acid with a charged one. The third group has the few mutations that affect amino acids in the cytoplasmic regions of the protein. Most of these affect the last few residues at the cytoplasmic end of the molecule.

Most of the mutations in the first two groups probably destroy the normal three dimensional conformation of rhodopsin. This conjecture relies on evidence that the intradiscal domains of rhodopsin are important in maintaining the shape of rhodopsin. ${ }^{45}$ It is consistent with the notion that adding charged amino acids to transmembrane domains probably destabilises those domains. Furthermore, many of the mutations in these groups involve proline residues, an amino acid that is important in protein folding. The cluster of mutations affecting amino acids near the disulfide bond connecting the first and second intradiscal loops also conforms with this idea, since this disulfide bond is also thought to be essential for a functional conformation of rhodopsin. ${ }^{45}$

Evidently, rhodopsin molecules with improper conformation are toxic to photoreceptors; what could be the reason? The explanation most appealing to me relates to the fact that rod photoreceptors normally synthesise a large amount of rhodopsin. New molecules of rhodopsin are synthesised daily by rods. Rhodopsin actually accounts for approximately $80 \%$ of all the protein in the rod outer segment, ${ }^{46}$ and approximately $10 \%$ of the outer segment is renewed each day. ${ }^{47}$ Now recall that 'old' rhodopsin is not catabolised intracellularly by rods. Instead, it is ingested daily be the neighbouring retinal pigment epithelial cells as they consume the tips of the rod outer segments. The normal situation is therefore that rods manufacture an abundance of a particular type of protein that they are not required to recycle. Envision what would occur if the rods could not utilise the retinal pigment epithelial 'disposal site' for this protein. Mutant rhodopsin molecules with improper conformation might not be transportable to the outer segment disc membrane, but instead might accumulate in the inner segments or other regions of the cell. In the framework of the model I propose, rods have no catabolic pathway to deal adequately with this load of mutant rhodopsin molecules. The presumed build up of rhodopsin molecules in the rods is what may lead to their demise.

Further support for this model comes from two sets of experiments done by other groups. The first deals with the glycosylation of rhodopsin. Carboyhydrate moieties are normally covalently bound to two asparagine residues near the amino terminus of the protein. This glycosylation is probably important to the normal transport of rhodopsin to the outer segment discs, because when rods are exposed to tunicamycin, an inhibitor of glycosylation, rhodopsin accumulates in the inner segment. ${ }^{48,49}$ One of the mutations found in dominant retinitis pigmentosa alters a threonine (at position 17) located two residues from one of the normally glycosylated asparagines (at position 15- see Figure II). ${ }^{50-52}$ The mutation is referred to as Thrl7Met. One requirement for glycosylation of an asparagine is that the amino acid two residues away be a threonine or a serine. Since the Thrl7Met converts the necessary threonine at this position to a methionine, glycosylation of asparagine-15 would be excluded. The results from the experiments with tunicamycin suggest that this mutant rhodopsin with defective glycosylation would accumulate in the inner segment.

Other data supporting this theory comes from the work of Nathans' group at Johns Hopkins. ${ }^{53}$ Wild-type and mutant forms of rhodopsin were expressed in vitro using COS cells. When wild-type rhodopsin is expressed, it is detectable on the surface of these cells, consistent with its expected affinity for cell membranes. However, most mutant forms of rhodopsin found in patients with dominant retinitis pigmentosa remain in the cytoplasm.

Again, the mutations in groups one and two (see Table IV) generally conform with the theory that the mutant rhodopsin might be toxic to photoreceptors because they may amass excessively in the cytoplasm. This explanation, although appealing, has a few weaknesses. First, it does not appear to explain the retinal degeneration associated with the mutant rhodopsins in group three, especially 


\section{AMINO ACIDS AFFECTED BY MUTATIONS IN AUTOSOMAL DOMINANT RETINITIS PIGMENTOSA}

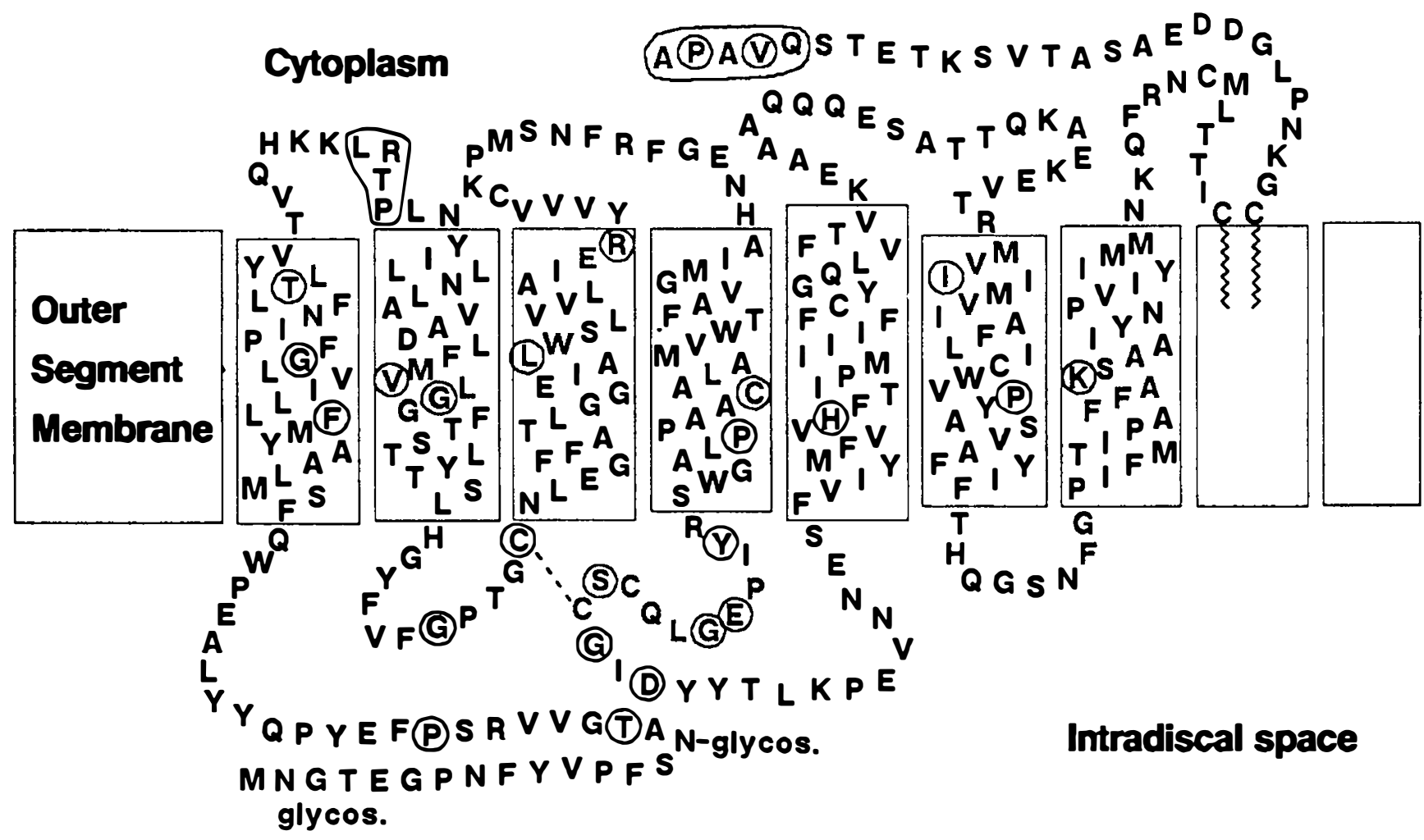

Fig. 2. Schematic model of rhodopsin. The protein is composed of 348 amino acids in a linear array, shown using the standard single letter code. The string of amino acids traverses the outer segment disc membrane seven times. The amino terminus of the protein is in the intradiscal space; the carboxy terminus is in the cytoplasm. Numbering of amino acids begins at the methionine residue at the amino terminus (' $M$ ' in the lower left hand corner of the figure.) The two glycosylation sites near the amino terminus are indicated with the abbreviation 'glycos', and are at amino acids 2 and 15. The lysine $(K)$ residue at position 296 to which 11 -cis-retinal is covalently bound is approximately in the middle of the seventh transmembrane domain (farthest one to the right). Circles indicate the amino acids affected by mutations in patients with autosomal dominant retinitis pigmentosa.

those mutations affecting the carboxy end of the molecule. Such mutant rhodopsins correctly assemble in the cell membrane when they are expressed in COS cells. ${ }^{53}$ Perhaps there is a signal sequence at this end of the molecule that is important for the intracellular transport of rhodopsin, an idea put forward by Paul Hargrave. When a mutation affects the signal sequence, rhodopsin might accumulate in the cell body in a fashion similar to what I propose for the other mutant rhodopsins. Another possible explanation is that the entire theory I have put forward here is mistaken; photoreceptor degeneration might be a consequence of some other absent, vital property or newly acquired, toxic property of the mutant rhodopsins.

Do the ophthalmological findings of the patients who carry these mutations help in understanding these forms of retinitis pigmentosa? Professor Eliot Berson, my close collaborator in this work, has meticulously examined the patients in whom we have found mutations. In view of the fact that rhodopsin is synthesised in the rods and not cones, the retinal degeneration in young cases more severely affects rod rather than cone function..$^{37.42 .54}$ This is evident by the fact that nyctalopia is a frequent early symptom of retinitis pigmentosa, and by the observation that electroretinograms (ERGs) show a greater reduction in the rod response compared with the cone response to flashes of light in early cases. In addition, the ERGs show a pathological delay between the stimulating flash of light and the rod response. ${ }^{37,42.54}$ One puzzling feature of rhodopsin-related dominant retinitis pigmentosa is that cones also degenerate as the disease progresses. Why should a defect in a rod-specific protein ultimately induce degeneration of cones as well? Perhaps the answer is a consequence of the small proportion of cones relative to rods in the human retina ( 5 million cones vs. 90 million rods). ${ }^{55}$ The surrounding large-scale destruction of rods might produce an environment too hostile for the scattered cones. However, the rod-specific nature of rhodopsin may provide a basis for future therapeutic approaches to this disease. If only one could devise a way to preserve cones, especially the macular cones, vision would be maintained.

Another question is whether the severity of the retinal degeneration is a function of the specific mutation in the rhodopsin gene a patient carries. It turns out that there is a considerable amount of variation in the severity of retinitis 
pigmentosa even among related patients with the same mutation. Despite this variation, the knowledge of which rhodopsin mutation a patient carries can have predictive value. For example, patients with the Pro23His mutation generally have a slower course than patients with Pro347Leu mutation, with both a greater ERG signal and a greater amount of remaining visual field at a given age. ${ }^{56}$ Most patients with Pro23His are expected to retain some useful vision well into the seventh decade of life, whereas patients with Pro347Leu would be expected to be blind many years earlier, on average. Too few patients have been examined with some of the other mutations to make statistically significant correlations regarding the clinical course of retinal degeneration. Nevertheless, the variations in severity among the patients with different mutations of the rhodopsin gene, reported by our group as well as others, ${ }^{54,57-62}$ makes it probable that each rhodopsin mutation will some day indicate to the ophthalmologist a particular clinical course and a forecast of the age at which a patient is most likely to lose all useful vision.

It is important to emphasise that not all patients with autosomal dominant retinitis pigmentosa carry a mutation in the rhodopsin gene. As mentioned earlier, only about 25 to $30 \%$ of cases are due to defects in this gene. The remaining autosomal dominant cases, not to mention cases with autosomal recessive and $\mathrm{X}$-linked disease, develop retinal degeneration due to mutations in other genes. Over the next few years, I expect that many of these other genes will be identified. At that time we should have a clearer picture of the range of genetic defects that cause this disease. Any properties that these genes or their protein products share might be clues to understanding the mechanisms for hereditary retinal degeneration. Hopefully, this knowledge will help in finding a therapy that can slow or stop the progressive loss of vision characteristic of all forms of retinitis pigmentosa.

In this lecture I have recounted in a historical fashion the approach that lead to the discovery that defects in the rhodopsin gene cause some forms of dominant retinitis pigmentosa. Molecular genetics techniques are extremely powerful and still improving. They are becoming easier and cheaper to perform and more widespread in their application. We should expect advances in our understanding of many hereditary eye diseases during our lifetimes. I especially await the identification of the gene causing the hereditary retinal disease that bears Professor Doyne's name, i.e. Doyne's honeycomb choroiditis. As an autosomal dominant condition, it should be straightforward for an interested ophthalmologist to collect blood samples from one or more large families with the disease and use either the linkage approach or the candidate gene approach to identify the responsible locus. Such a study might provide a fundamental insight into age-related macular degeneration, a common disease of the elderly for which we know too little about the pathogenesis. I predict that in the next 20 years the 'Doyne's gene' will be isolated. The responsible investigator will no doubt be honoured by an invitation to this Congress to present the
Doyne Memorial Lecture. I trust that he will enjoy the hospitality and fellowship you have so kindly bestowed on me.

\section{REFERENCES}

1. Chen JD, Halliday F, Keith G, Sheffield L, Dickinson P, Gray R, Constable I, Denton M: Linkage heterogeneity between $\mathrm{X}$-linked retinitis pigmentosa and a map of 10 RFLP loci. Am J Hum Genet 1989, 45: 401-11.

2. Kimberling WJ, Moller CG, Davenport SLH, Lund G, Grissom TJ, Priluck I, White V, Weston MD, Biscone-Halterman $\mathrm{K}$, Brookhouser PE: Usher syndrome: clinical findings and gene localisation studies. Laryngoscope 1988, 99: 66-72.

3. Kimberling WJ, Weston MD, Moller C, Davenport SL, Shugart YY, Priluck IA, Martini A, Milani M, Smith RJ: Localisation of Usher syndrome type II to chromosome 1q. Genomics 1990, 7: 245-9.

4. Kolb, J and Gouras P: Electron microscopic observations of human retinitis pigmentosa, dominantly inherited. Invest Ophthalmol Vis Sci 1974, 13: 487-98.

5. Verhoeff FH: Microscopic observations in a case of retinitis pigmentosa. Arch Ophthalmol 1931, 5: 392-407.

6. Friedenwald J: Discussion of Verhoeff's observations of pathology of retinitis pigmentosa. Arch Ophthalmol 1930, 4: 767-70.

7. Cogan DG: Pathology [of retinitis pigmentosa]. Trans Am Acad Ophthalmol Otolaryngol 1950, 54: 629-61.

8. Szamier RB and Berson EL: Histopathologic study of an unusual form of retinitis pigmentosa. Invest Ophthal Vis Sci 1982, 22: 559-70.

9. Flannery JG, Farber DB, Bird AC, Bok D: Degenerative changes in a retina affected with autosomal dominant retinitis pigmentosa. Invest Ophthalmol Vis Sci 1989, 30: 191-211.

10. Szamier RB, Berson EL, Klein R, Meyers S: Sex-linked retinitis pigmentosa: ultrastructure of photoreceptors and pigment epithelium. Invest Opthalmol Vis Sci 1979, 18: 145-60.

11. Boughman JA, Conneally PM, Nance WE: Population studies of retinitis pigmentosa. Am J Hum Genet 1980, 32: 223-35.

12. Bunker CH, Berson EL, Bromley WC, Hayes RP, Roderick TH: Prevalence of retinitis pigmentosa in Maine. Am J Ophthalmol 1984, 97: 357-65.

13. Royer-Pokora B, Kunkel IM, Monaco AP, Goff SC, Newburger PE, Baehner RL, Cole FS, Curnutte JT, Orkin SH: Cloning the gene for an inherited human disorder-chronic granulomatous disease - on the basis of its chromosomal location. Nature 1986, 322: 32-8.

14. Monaco AP, Neve RL, Colletti-Feener C, Bertelson CJ, Kurnit DM, Kunkel IM: Isolation of candidate cDNAs for portions of the Duchenne muscular dystrophy gene. Nature 1986, 323: 646-50.

15. Rommens JM, Iannuzzi MC, Kerem B, Drumm ML, Melmer G, Dean M, Rozmahel R, Cole JL, Kennedy D, Hidaka N, Zsiga M, Buchwald M, Riordan JR, Tsui LC, Collins FS: Identification of the cystic fibrosis gene: chromosome walking and jumping. Science 1989, 245: 1059-65.

16. Riordan JR, Rommens JM, Kerem B, Alon N, Rozmahel R, Grzelczak Z, Zielenski J, Lok S, Plavsic N, Chou JL, Drumm ML, Iannuzzi MC, Collins FS, Tsui LC: Identification of the cystic fibrosis gene; cloning and characterisation of complementary DNA. Science 1989, 245: 1066-73.

17. Kerem B, Rommens JM, Buchanan JA, Markiewicz D, Cox TK, Chakravarti A, Buchwald M, Tsui LC: Identification of the cystic fibrosis gene: genetic analysis. Science 1989, 245: 1073-80.

18. Friend SH, Bernards R, Rogelj S, Weinberg RA, Rapaport 
JM, Albert DM, Dryja TP: A human DNA segment with properties of the gene that predisposes to retinoblastoma and osteosarcoma. Nature 1986, 323: 643-6.

19. Gusella JF, Wexler NS, Conneally PM, Naylor SL, Anderson MA, Tanzi RE, Watkins PC, Ottina K, Wallace MR, Sakaguchi AY, et al: A polymorphic DNA marker genetically linked to Huntingdon's disease. Nature 1983, 306: 234-8.

20. Nathans $J$ and Hogness DS: Isolation and nucleotide sequence of the gene encoding human rhodopsin. Proc Natl Acad Sci USA 1984, 81: 4851-5.

21. Si JSS, Borst DE, Redmond TM, Nickerson JM: Cloning of cDNAs encoding human interphotoreceptor retinoid-binding protein (IRBP) and comparison with bovine IRBP sequences. Gene 1989, 80: 99-108.

22. Fong SL, Fong WB, Morris TA, Kedzie KM, Bridges CDB: Characterisation and comparative structural features of the gene for human interstitial retinol-binding protein. $J$ Biol Chem 1990, 265: 3648-53.

23. Crabb JW, Goldflam S, Harris SE, Saari JC: Cloning of the cDNA's encoding the cellular retinaldehyde binding protein from bovine and human retina and comparison of the protein sequences. J Biol Chem 1988, 263: 18688-702.

24. Yamaki K, Tsuda M, Shinohara T: The sequence of human retinal $S$-antigen reveals similarities with alpha-transducin. FEBS Lett 1988, 234: 39-43.

25. Lerea CL, Bunt-Milam AH, Hurley JB: Alpha transducin is present in blue-, green-, and red-sensitive cone photoreceptors in the human retina. Neuron 1989, 3: 367-76.

26. Ovchinnikov YA, Lipkin VM, Kumarev VP, Gubanov VV, Khramtsov NV, Akhmedov NB, Zagranichny VE, Muradov KG: Cyclic GMP phosphodiesterase from cattle retina. Amino acid sequence of the gamma-subunit and nucleotide sequence of the corresponding cDNA. FEBS Lett 1986, 204: 288-92.

27. Tuteja N and Farber DB: Gamma-subunit of mouse retinal cyclic-GMP phosphodiesterase cDNA and corresponding amino acid sequence. FEBS Lett 1988, 232: 182-6.

28. Ringens PJ, Fang M, Shinohara T, Bridges CD, Lerea CL, Berson EL, Dryja TP: Analysis of genes coding for S-antigen, interstitial retinol binding protein, and the alpha-subunit of cone transducin in patients with retinitis pigmentosa. Invest Ophthal Vis Sci 1990, 31: 1421-6.

29. Cotran PR, Ringens PJ, Crabb JW, Berson EL, Dryja TP. Analysis of the DNA of patients with retinitis pigmentosa with a cellular retinaldehyde binding protein cDNA. Exp Eye Res 1990, 51: 15-19.

30. Cotran PR, Bruns GAP, Berson EL, Dryja TP: Genetic analysis of patients with retinitis pigmentosa using a cloned cDNA probe for the human gamma subunit of cyclic GMP phosphodiesterase. Exp Eye Res 1991, 53: 557-64.

31. Liou GI, Li Y, Wang C, Fong SL, Bhattacharya S, Bridges CDB: BglII RFLP recognised by a human IRBP cDNA localised to chromosome 10. Nuc Acids Res 1987, 15: 3196.

32. Simpson NE, Kidd KK, Goodfellow PJ, Dermid HM, Myer S, Kidd JR, Jackson CE, Duncan AMV, Farrer LA, Brasch $\mathrm{K}$, Castiglione C, Genel M, Gertner J, Greenberg CR, Gusella JF, Holden JJA, White BN: Assignment of multiple endocrine neoplasia type $2 \mathrm{~A}$ to chromosome 10 by linkage. Nature 1987, 328: 528-30.

33. Nathans J, Piantanida TP, Eddy RL, Shows TB, Hogness DS: Molecular genetics of inherited variation in human colour vision. Science 1986, 232: 203-10.

34. Sparkes RS, Klisak I, Kaufman D, Mohandas T, Tobin AJ, McGinnis J: Assignment of the rhodopsin gene to human chromosome three, region $3 \mathrm{q} 21-3 \mathrm{q} 24$ by in situ hybridisation studies. Curr Eye Res 1986, 5: 797-8.

35. Yandell DW, Campbell TA, Dayton SH, Petersen R, Walton D, Little JB, McConkie-Rosell A, Buckley EG, Dryja TP: Identification of oncogenic point mutations in the human retinoblastoma gene and application to genetic counseling. N Eng J Med 1989, 321: 1689-95.

36. Yandell DW and Dryja TP: Direct genomic sequence of alleles at the human retinoblastoma locus: application to cancer diagnosis and gentic counseling. In: Furth $\mathbf{M}$, Greaves M, eds. Cold Spring Harbour Symposium Series: Cancer Cells 7-Molecular Diagnostics of Human Cancer. Cold Spring Harbor: Cold Spring Harbour Press, 1989: 223-227.

37. Dryja TP, McGee TL, Reichel E, Hahn LB, Cowley GS, Yandell DW, Sandberg MA, Berson EL: A point mutation of the rhodopsin gene in one form of retinitis pigmentosa. Nature 1990, 343: 364-6.

38. Applebury ML and Hargrave PA: Molecular biology of the visual pigments. Vision Res 1986, 12: 1881-95.

39. Baehr W, Falk JD, Bugra K, Triantafyllos JT, McGinnis JF: Isolation and analysis of the mouse opsin gene. FEBS Lett 1988, 238: 253-6.

40. Pappin DJC, Eliopoulos E, Brett M, Findlay JBC: A structural model for ovine rhodopsin. Int J Biol Macromol 1984, 6: $73-6$.

41. Weber JL and May PE: Abundant class of human DNA polymorphisms which can be typed using the polymerase chain reaction. Am J Hum Genet 1989, 44: 388-96.

42. Dryja TP, McGee TL, Hahn LB, Cowley GS, Olsson JE, Reichel E, Sandberg MA, Berson EL: Mutations within the rhodopsin gene in patients with autosomal dominant retinitis pigmentosa. $N$ Eng J Med 1990, 323: 1302-7.

43. Bhattacharya S, Lester D, Keen TJ, Bashir R, Lauffart B, Inglehearn CF, Jay M, Bird AC: Retinitis pigmentosa and mutations in rhodopsin. Lancet 1991, 337: 185.

44. Fujiki K, Hotta Y, Shiono T, Hayakawa M, Noro M, Sakuma T, Tamai M, Nakajima A, Kanai A: Codon 347 mutation of the rhodopsin gene in a Japanese family with autosomal dominant retinitis pigmentosa. Am J Hum Genet 1991, 49(Suppl): 187.

45. Doi T, Molday RS, Khorana HG: Role of the intradiscal domain in rhodopsin assembly and function. Proc Natl Acad Sci USA 1990, 87: 4991-5.

46. Papermaster DS, Dreyer WJ: Rhodopsin content in the outer segment membranes of bovine and frog retinal rods. Biochem 1974, 13: 2438-44.

47. Young RW: Visual cells and the concept of renewal. Invest Ophthalmol Vis Sci 1976, 15: 700-25.

48. Fliesler SJ, Rayborn ME, Hollyfield JG: Membrane morphogenesis in retinal rod outer segments: inhibition by tunicamycin. J Cell Biol 1985, 100: 574-87.

49. Ulshafer RJ, Allen CB, Fliesler SJ: Tunicamycin-induced dysgenesis of retinal rod outer segment membranes. Invest Ophthal Vis Sci 1986, 27: 1587-601.

50. Sheffield VC, Fishman GA, Beck JS, Kimura AE, Stone EM: Identification of novel rhodopsin mutations associated with retinitis pigmentosa by GC-clamped denaturing gradient gel electrophoresis. Am J Hum Genet 1991, 49: 699-706.

51. Dryja TP, Hahn LB, Cowley GS, McGee TL, Berson EL: Mutation spectrum of the rhodopsin gene among patients with autosomal dominant retinitis pigmentosa. Proc Nat Acad Sci USA 1991, 88: 9370-4.

52. Sung CH, Davenport CM, Hennessey JC, Maumenee IH, Jacobson SG, Heckenlively JR, Nowakowski R, Fishman G, Gouras P, Nathans J: Rhodopsin mutations in autosomal dominant retinitis pigmentosa. Proc Natl Acad Sci USA 1991, 88: 6481-5.

53. Sung CH, Schneider BG, Agarwal N, Papermaster DS, Nathans J: Functional heterogeneity of mutant rhodopsin responsible for autosomal dominant retinitis pigmentosa. Proc Natl Acad Sci USA 1991, 88: 8840-4.

54. Berson EL, Rosner B, Sandberg MA, Dryja TP: Ocular findings in patients with autosomal dominant retinitis pigmen- 
tosa and a rhodopsin gene defect (Pro23His). Arch Ophthalmol 1991, 109: 92-101.

55. Curcio CA, Sloan KR, Kalina RE, Hendrickson AE: Human photoreceptor topography. J Comp Neurol 1990, 292: 497-523.

56. Berson EL, Rosner B, Sandberg MA, Weigel-DiFranco C, Dryja TP: Ocular findings in patients with autosomal dominant retinitis pigmentosa and rhodopsin, proline-347-leucine. Am J Ophthalmol 1991, 111: 614-23.

57. Jacobson SG, Kemp CM, Sung CH, Nathans J: Retinal function and rhodopsin levels in autosomal dominant retinitis pigmentosa with rhodopsin mutations. Am J Ophthalmol 1991, 112: 256-71.

58. Fishman GA, Stone EM, Gilbert LD, Kenna P, Sheffield VC: Ocular findings associated with a rhodopsin gene codon 58 tranversion mutation in autosomal dominant retinitis pigmentosa. Arch Ophthalmol 1991, 109: 1387-93.

59. Berson EL, Sandberg MA, Dryja TP: Autosomal dominant retinitis pigmentosa with rhodopsin, valine-345-methionine. Trans Am Ophthalmol Soc 1991; (in press).

60. Heckenlively JR, Rodriguez JA, Daiger SP: Autosomal dominant sectoral retinitis pigmentosa. Two families with transversion mutation in codon 23 of rhodopsin. Arch Ophthalmol 1991, 109: 84-91.

61. Richards JE, Kuo CY, Boehnke M, Sieving PA: Rhodopsin Thr58Arg mutation in a family with autosomal dominant retinitis pigmentosa. Ophthalmology 1991, 98: 1797-805.
62. Stone EM, Kimura AE, Nichols BE, Khadivi P, Fishman GA, Sheffield VC: Regional distribution of retinal degeneration in patients with the proline to histidine mutation in codon 23 of the rhodopsin gene. Ophthalmology 1991, 98: 1806-13.

63. Sorscher EJ and Huang Z: Diagnosis of genetic disease by primer-specified restriction map modification, with application to cystic fibrosis and retinitis pigmentosa. Lancet 1991, 337: 1115-18.

64. Farrar GJ, Kenna P, Redmond R, Shiels D, McWilliam P, Humphries MM, Sharp EM, Jordan S, Kumar-Singh R, Humphries P: Autosomal dominant retinitis pigmentosa: a mutation in codon 178 of the rhodopsin gene in two families of Celtic origin. Genomics 1991, 11: 1170-1.

65. Keen TJ, Inglehearn CF, Lester DH, Bashir R, Jay M, Bird AC, Jay B, Bhattachary SS: Autosomal dominant retinitis pigmentosa: four new mutations in rhodopsin, one of them in the retinal attachment site. Genomics 1991, 11: 199-205.

66. Inghlehearn CF, Bashir R, Lester DH, Jay M, Bird AC, Bhattacharya SS: A 3-bp deletion in the rhodopsin gene in a family with autosomal dominant retinitis pigmentosa. Am J Hum Genet 1991, 48: 26-30.

67. Gal A, Artlich A, Ludwig M, Niemeyer G, Olek K, Schwinger E, Schinzel A: Pro347Arg mutation of the rhodopsin gene in autosomal dominant retinitis pigmentosa. Genomics 1991, 11: 468-70. 